ISSN 1045-6333

\title{
HARVARD
}

JOHN M. OLIN CENTER FOR LAW, ECONOMICS, AND BUSINESS

\author{
THE EFFECTS OF TORT REFORM \\ ON MEDICAL MALPRACTICE INSURERS' \\ ULTIMATE LOSSES
}

\author{
Patricia Born, W. Kip Viscusi \\ \& Tom Baker
}

Discussion Paper No. 554

$07 / 2006$

Harvard Law School

Cambridge, MA 02138

This paper can be downloaded without charge from:

The Harvard John M. Olin Discussion Paper Series:

http://www.law.harvard.edu/programs/olin_center/

The Social Science Research Network Electronic Paper Collection: http://papers.ssrn.com/abstract_id=\#\#\#\#\# 
JEL Classification: K13, G22

\title{
The Effects of Tort Reform on Medical Malpractice Insurers' Ultimate Losses

\author{
Patricia Born", W. Kip Viscusi** ${ }^{* *}$ and Tom Baker ${ }^{* * *}$
}

\begin{abstract}
Whereas the literature evaluating the effect of tort reforms has focused on reported incurred losses, this paper examines the long run effects using a comprehensive sample by state of individual firms writing medical malpractice insurance from 1984-2003. The long run effects of reforms are greater than insurers' expected effects, as five year developed losses and ten year developed losses are below the initially reported incurred losses for those years following reform measures. The quantile regressions show the greatest effects of joint and several liability limits, noneconomic damages caps, and punitive damages reforms for the firms that are at the high end of the loss distribution. These quantile regression results show stronger, more concentrated effects of the reforms than do the OLS and fixed effects estimates for the entire sample.
\end{abstract}

keywords: medical malpractice, tort reform, insurance

\footnotetext{
* California State University, Northridge. Corresponding author. Please send any comments and suggestions to the author at patricia.born@csun.edu.

** Cogan Professor of Law \& Economics, Harvard Law School, 1575 Massachusetts Avenue, Cambridge, MA 02138. phone: 617-496-0019 e-mail: kip@law.harvard.edu. Viscusi's research is supported by the Harvard Olin Center for Law, Economics, and Business and the Program on Empirical Legal Studies. ${ }^{* * *}$ University of Connecticut School of Law.
} 


\section{The Effects of Tort Reform on Medical Malpractice Insurers' Ultimate Losses}

Patricia Born, W. Kip Viscusi, and Tom Baker

(C) 2006 Patricia Born, W. Kip Viscusi, and Tom Baker. All rights reserved.

\section{Introduction}

Since the 1970s, the medical malpractice insurance industry has experienced several periods in which profits have declined rapidly, premiums have risen, and medical providers have reported problems with availability and affordability. To reduce the costs of insurance, many states have enacted a variety of tort reform measures that will reduce award and settlement amounts. There have been three distinct "rounds" of tort reformthe mid-1970s, mid-1980s, and the late 1990s. The influence of such reforms on the medical malpractice insurance industry is of renewed interest because there are increased pressures for additional reform efforts. Medical malpractice currently heads the Bush administration's tort reform agenda.

The focus of the reform efforts has been on various measures that will reduce the amount of losses incurred by the insured. Whether such reforms are desirable from a social policy standpoint is beyond the scope of this study. We should note that a decrease in the amount of losses borne by the insurer typically implies that less money will be paid to injured parties though tort reform is generally not strictly a zero sum game. This paper is concerned with the more narrowly framed empirical issue of whether the reforms did in fact reduce losses, which was their primary intent.

The empirical novelty of our analysis is that it is the first study to assess the longer term effects of the reforms on losses. We consider this "longer term" to be a period of time in which: (1) the losses have been nearly fully developed, and (2) the 
insurer has had time to correspondingly adjust premiums to reflect the changes in expected losses. To date, insurance-related studies of malpractice crises have focused mainly the shorter term results of tort reform, looking at how insurer losses and loss ratios vary across states with different sets of reforms. These studies use reported losses in calculating the influence of the reform variables, and thus capture the influence of the reforms as "perceived" by the insurer (Barker, 1992; Viscusi et al, 1993; Viscusi and Born, 1995; Born and Viscusi, 1998; and Viscusi and Born, 2004). The results of these studies indicate, among other things, that the most influential malpractice reform measure is the cap on noneconomic damages, which have had significant effects on reducing incurred losses. These findings are further substantiated by the results of a line of research that focuses on the effects of the reforms on insurance company closed claim data (Danzon, 1984; Danzon, 1986; Sloan et al, 1989; Zuckerman et al, 1990; Yoon, 2001). These studies indicate that caps on damages reduce mean payments in medical malpractice cases. Thus, we would expect a subsequent effect on insured losses.

Yet another line of research on the effects of malpractice tort reforms focuses on the effects of the reforms on award payments (Pace, 2004; Studdert et al., 2004). These studies indicate that caps on non-economic damages did, in fact, result in reduced payments to plaintiffs in cases in which the jury had awarded non-economic damages in excess of the maximum allowable amount. While of course this result is unsurprising, it does confirm that caps do have an impact on tried cases. ${ }^{1}$ While examination of court

\footnotetext{
${ }^{1}$ Sharkey (2005) argues that much of the research on the impact of damages caps has ignored the unintended consequences of the caps, such as possible "anchoring" by the jury (jurors may learn of the existence of the cap from the news media), and the "crossover effect" in which plaintiffs lawyers work harder to increase economic damages in states in which non-economic damages are capped (Baker, 1998). She studied the relationship between damages caps and awards in tried cases using cross sectional data obtained from the National Center for State Courts and the Bureau of Justice Statistics. While both the
} 
awards is interesting, focusing on court awards alone ignores the effect of caps on settlements and on the selection of cases for litigation, which in turn will affect award levels. Our analysis of insurer losses will assess the full effects of tort reforms, not simply one aspect of these influences.

Our longer term analysis of the effect of the tort reforms will also provide a more accurate perspective on the reform effects. If tort reforms did not alter the temporal profile of losses, then analyses based on reported losses would be an accurate reflection of the reform effects. However, the reform may also alter the time path of subsequent losses associated with the policy, given the long tail of medical liability insurance and the time it takes for reforms to have their full effect on court awards. An assessment of the ultimate effects of the tort reforms on losses requires analysis of the developed losses, which capture the actual court and settlement outcomes as influenced by the reforms. Furthermore, the analysis of the reforms over a longer period of time will illustrate whether some types of reforms take longer to work their way through the system if, for example, they affect how cases are handled generally so that case law has to develop before the effects are realized.

In this article, we use a combination of OLS and quantile regression models to assess the relationships between various tort reform measures and insurer losses. To the extent that the results differ from earlier studies based on contemporaneous measures of losses and loss adjustment expenses, it is because we have additional information on (1) the true impact of the malpractice reforms on insurer underwriting performance and (2)

mean and median award were lower in states with damage caps, when she controlled for injury severity, county characteristics, litigant characteristics, and whether judges are elected or appointed, she found that the relationship was not significant (although the direction and magnitude of the effect in her regression equation was consistent with the differences in the means). 
the extent to which perceived effects of the reforms were actually borne out in the legal system. We discuss the construction of our dataset in the next section. This discussion is followed by an illustration of the substantial effect of loss development, which provides further motivation for our particular analytical approach. Our empirical approach and results of our analysis follow, along with our discussion and conclusions. We find that considering the effect of the reforms on losses using both five year and ten year development factors shows that the long run effect of the reforms differs substantially from the short run effects. Typically the effects are greater in the long run, but the relative impact of the reforms and the distribution of the reform effects throughout the insurance market are influenced as well by our use of a longer term perspective.

\section{Data and Methodology}

The empirical analysis uses the financial data that insurers submit annually to the National Association of Insurance Commissioners (NAIC). These statements contain detailed information about the insurer's underwriting experience, including by-line and by-state premiums and losses, overall reserves and by-line developed losses incurred. For our analysis, we utilized information from all statements filed by insurers active in underwriting for medical malpractice liability between 1984 and 2003.

Premiums earned were drawn from the annual statements, Schedule P1 Part F. We took data on losses incurred and loss development from Schedule P2 Part F. For each year in which premiums are earned, we obtained contemporaneous losses incurred

\footnotetext{
${ }^{2}$ In the early 1990s, insurers began reporting separately their premium and loss information for two types of medical malpractice policies: claims made and occurrence. An insurer's business for the two types was simply added for this research project, but this distinction will be explored in subsequent research.
} 
and the revised estimates of losses incurred (i.e., development) in each of the next 9 years.

Additional variables drawn from the NAIC data include the number of states in which the insurer operates and the insurer's organizational form. Considering the number of states in which the insurer operates helps to capture the degree to which the insurer is able to diversify operations across different regulatory and legal environments. Organizational form is included in the analysis to reflect possible differentials in administrative costs and agency issues across the major forms of insurer ownership: stocks, mutuals, reciprocals, and Lloyds. Table 1 presents the sample means of the insurer variables used in the analysis.

Insurer loss development data is only reported at the firm level, and cannot reasonably be allocated to state operations. This aspect of the data complicates our analysis of the influence of state differences in tort reform activity and regulation on insurer performance. Following Born (2001), we created proxy variables to capture the state differences in tort reform and rate regulation. For each individual insurer operating in one or more states, we created variables to capture the extent to which that insurer is exposed to business in states with a particular characteristic, e.g., a reform measure. Each of these variables was calculated in the same manner, using 853,048 firm/state/yearlevel observations on medical malpractice liability premiums written. E.g., the joint and several liability variable for firm $i$ in year t operating in states indexed by $s$ is given by

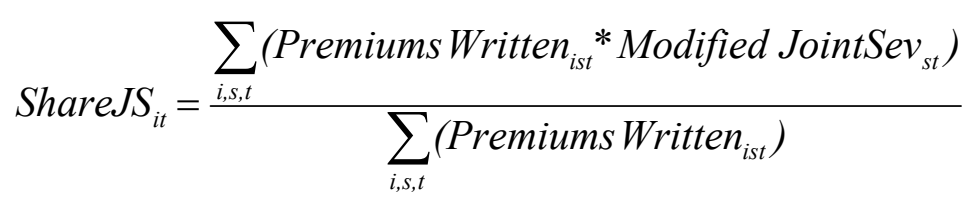


where ModifiedJointSev st $=1$ for each state, $s$, with this reform in place in year $t$, and 0 otherwise. The average share values for the four reform measures increase through the sample period, indicating that the amount of business written in reformed environments increased, which is consistent with state reform activity. The average values for all insurer share variables in 1984, 1992, and 2003 are shown in Table 2.

The prevalence of the tort reform regimes differs across states. As indicated in Table 1, the average share of the business in states with modified joint and several liability or modified collateral source rules is 40 percent, while the prevalence of caps on noneconomic damages or punitive damages is half that. The temporal shifts in the reform variables vary as well, as reflected in Table 2. In 1984 there were few of these limitations in place, whereas by 1992 over one third of the insurer share of business was in states with modified joint and several liability and modified collateral source rules. By 2003, the average share of business in states with punitive damages caps doubled from the 1992 level. The effect these various measures will have on losses will depend not only on their prevalence but also on the extent to which these various reforms impinge on the levels of damages that plaintiffs would otherwise receive.

\section{Loss Development}

Earlier studies of the effects of tort reform on insurer performance made use of current year reported loss information. Reported incurred losses include losses paid and an estimate of losses incurred but not yet reported. The reported figure represents, to some extent, an insurer's expectations of the ultimate payout for policies in that year. 
This expectation is formed by past experience, whereby the insurer can use past payout history to estimate the ultimate losses if the book of business and types of risks borne by the insurer have not changed markedly.

Insurers use a variety of methods to evaluate the development of losses over time. Reported losses are adjusted to correct for errors in the estimation of loss reserves. These errors arise from two primary factors: (1) delays in the reporting of claims, and (2) misjudgments in calculating the value of claims. As time passes, the number and value of claims for a particular policy year become more evident. The pattern of loss development can be estimated using past experience, and this projection is essential to the insurer's reserving for future losses.

The relationship between reported and developed losses has been the focus of several different veins of research. Several studies offer a behavioral perspective, suggesting that insurance company managers may intentionally misreport losses to achieve corporate or even personal objectives. ${ }^{3}$ Unintentional misreporting results from unforeseen exogenous influences, such as a higher than expected inflation rate which causes higher than expected claims payments (Weiss, 1985). Significant errors in loss estimates make it difficult to evaluate an insurer's true financial performance. The implications of misreported losses are especially important to reinsurers, who rely greatly on the insurer's estimates of loss development patterns. A recent study suggests that from 1983-1993 property-casualty insurers were systematically overstating their loss reserves (Bierens and Bradford, 2005).

\footnotetext{
${ }^{3}$ These errors have direct effects on the insurer's reported financial results, allowing managers to justify price increases (Nelson, 2000), manipulate tax payments, and smooth earnings over time (Grace, 2000). Over-estimating reduces reported earnings, decreases reported capital surpluses, reduces tax liabilities, and can ward off regulatory scrutiny (Petroni, 1992; Gaver and Paterson,1999).
} 
In the period we analyze, medical malpractice insurers' loss expectations must take into account the largely unknown effects of state tort reform activity on the legal outcomes for which the insurer may be liable. To the extent that past experience does not prove helpful in estimating reserves, we expect that the level of incurred losses reported in a given year may be significantly different than the level reported for that same year of policies in subsequent years.

Figure 1 shows the pattern of industry losses based on initial reports and subsequent development for the time period we analyze. The figure indicates the reported losses in each year as well as the developed losses after five and ten years. Although the loss statistics follow a similar pattern of increases and decreases over time, the gap between reported and developed losses is quite different. In the early 1980s developed losses are higher than initially reported, which suggests that the long run loss experience during that period was worse than insurers had predicted. The reverse is true from 19861997: developed losses are lower than amounts initially reported, and further development, i.e., from 5 years to 10 years, results in additional reductions in the loss amounts. Although development of losses since 1997 is not complete, the developed losses appear to be greater than reported losses.

\section{Empirical Analysis}

If the malpractice tort reforms are influential in affecting insurer performance, then these effects will be evident in the level of losses. Insurer losses are reduced if these reforms have the intended effect of decreasing award and settlement amounts and the number of claims that are litigated. We begin by applying ordinary least squares (OLS) 
regression methodology to obtain estimates of the reform effects on reported losses, using the following loss equation for firm $i$ at time $t$ :

Log Losses Incurred $_{i t}=$

$$
\begin{aligned}
\alpha & +\beta_{1} \text { Log Premiums Earned }_{i t} \\
& +\beta_{2} \text { ShareJS }_{i t}+\beta_{3} \text { ShareCS }_{i t}+\beta_{4} \text { SharePD }_{i t}+\beta_{5} \text { ShareND }_{i t} \\
& +\beta_{6} \text { Sharereg }_{i t}+\beta_{7} \text { Log Number of States }_{i t} \\
& +\beta_{8} \text { Lloyds }_{i}+\beta_{9} \text { Mutual }_{i}+\beta_{10} \text { Reciprocal }_{i}+\beta_{11} \text { TBill }_{i}+\varepsilon_{i j t} .
\end{aligned}
$$

To allow for the influence of omitted insurer characteristics, we estimate the equation using a fixed effects model as well. The model takes the form:

$$
\begin{aligned}
& \text { Log Losses Incurred }_{i t}= \\
& \qquad \alpha_{0}+\sum \alpha_{i} \text { Firm }_{i}+\beta_{1} \text { Log Premiums Earned }_{i t} \\
& \quad+\beta_{2} \text { ShareJS }_{i t}+\beta_{3} \text { ShareCS }_{i t}+\beta_{4} \text { SharePD }_{i t}+\beta_{5} \text { ShareND }_{i t} \\
& \quad+\beta_{6} \text { Sharereg }_{i t}+\beta_{7} \text { Log Number of States }_{i t} \\
& \quad+\beta_{8} \text { Lloyds }_{i}+\beta_{9} \text { Mutual }_{i}+\beta_{10} \text { Reciprocal }_{i}+\beta_{11} \text { TBill }_{i}+\varepsilon_{i j t} .
\end{aligned}
$$

where Firm $_{i}$ is a $0-1$ dummy variable for firm $i(i=2, \ldots N)$, and the estimates of $\alpha_{i}$ capture the presence of any statistically significant group effects.

The influence of the tort reforms may vary depending on the type of reform and the nature of the insurer's loss exposure. If the reforms work to limit award amounts, rather than completely eliminating them, then the effects of such measures should 
increase with the size of the financial stakes involved in the case. Likewise, we would expect little effect on cases that are very small. The reforms are therefore likely to be particularly influential in dampening the losses of firms that are at the high end of the loss distribution. To evaluate the potential differential influence on loss levels of the reform measures we utilize a quantile regression analysis. Equation (3) is the quantile regression counterpart of our linear regression (1):

$$
\operatorname{Quant}_{\tau}(\log \operatorname{Losses} \mid x)=\beta_{\tau}{ }^{\prime} x \text {, }
$$

where $\beta_{\tau}$ is the vector of coefficients for the explanatory variables $x$ at the $\tau^{\text {th }}$ percentile. $^{4}$ More specifically, the estimates will determine the differential effects of the variables $x$ at the $10^{\text {th }}, 25^{\text {th }}, 50^{\text {th }}, 75^{\text {th }}$, and $90^{\text {th }}$ percentiles of the $\log$ loss ratio distribution. ${ }^{5}$ The estimator for our quantile regression model is

$$
\operatorname{Min}_{\beta} \frac{1}{\mathrm{n}} \sum_{i=1}^{n}\left[\tau \rho\left(L R_{i} \geq \beta^{\prime} \chi_{i}\right)+(1-\tau) \rho\left(L R_{i} \geq \beta^{\prime} \chi_{i}\right)\right]\left|L R_{i}-\beta^{\prime} \chi_{i}\right|
$$

where the sample size is $n$ and $\rho$ is an indicator function that assumes a value of 1 when the inequality holds; otherwise, it is zero. To estimate the asymptotic standard errors we use a bootstrapping technique.

Results of estimating equations (1) - (3) are shown in Table 3. As expected, the contemporaneous value of premiums earned is strongly related to the insurer's reported loss experience for every set of results. ${ }^{6}$ In the first OLS model, two of the four tort

\footnotetext{
${ }^{4}$ See Koenker and Bassett $(1978,1982)$ for a description of the approach.

${ }^{5}$ The quantile regression at, for example, the $90^{\text {th }}$ percentile will fit an equation such that 90 percent of the sum of the absolute value of the residuals will involve negative errors and 10 percent will be positive. The large loss firms will tend to be captured at this high quantile. Because we include a measure of earned premiums in the equation, the "large loss" firms are those firms with high losses given their premiums; they are not necessarily the large firms.

${ }^{6}$ Since the reform effects are evaluated using firm-level data, the estimated effects are not directly comparable to those obtained earlier using firm-state-level data. Nevertheless, the significant results are consistent with earlier findings (See Born \& Viscusi, 1998).
} 
reform variables have a significant negative effect on losses: punitive damages reforms and joint and several liability reforms. Somewhat surprisingly, noneconomic damages reforms are not influential despite their prominence in recent reform discussions. However, the lack of significance in the overall OLS regressions may be because these reforms were not that prevalent during the period of analysis and also because tort reforms my only affect a segment of the distribution of losses, which will be explored using the quantile estimates.

Only one of the reform variables is significant when the OLS model is reestimated with firm fixed effects. The results indicate that the joint and several liability reforms were most influential in reducing losses.

The quantile regression effects provide a different perspective in that these results make it possible for us to analyze the incidence of the reform effects across different percentiles of the loss distribution. Firms with losses at the upper end of the loss distribution benefit the most from tort reforms, with all four reform variables having a significant negative effect on losses at the $75^{\text {th }}$ percentile and three of the four reform variables having a significant negative effect at the $90^{\text {th }}$ percentile. The magnitudes of the effects of noneconomic damages caps, punitive damages caps, and joint and several liability reforms are greatest at the $90^{\text {th }}$ percentile. Notably, noneconomic damages limits are influential for the high loss firms in the $75^{\text {th }}$ and $90^{\text {th }}$ percentiles even though these reforms did not have a significant effect overall in the OLS regressions. Few of the lower quantiles exhibit significant influence of the tort reform measures, which suggests that any restraining effect of the reforms appears to be largely concentrated at the upper tail. 
The reported losses that are the basis for the estimates in Table 3 are largely estimated, so that it is useful to assess whether the performance of actual loss experiences accord with what insurers expected their losses to be. By evaluating the effects of the reforms on developed losses, we can assess whether their expectations were correct. Moreover, analysis of developed losses provides a more accurate picture of the ultimate effects of the reform measures. Tables 4 and 5 present the results of estimating equations (1) - (3), where the dependent variables are losses developed to the $5^{\text {th }}$ year and losses developed to the $10^{\text {th }}$ year, respectively. While Table 3 contains all insurers writing medical malpractice insurance between 1984 and 2003, the time periods covered in Table 4 (1984-1998) and Table 5 (1984-1993) are necessarily reduced.

The effects of the tort reforms on losses tend to be greater in the developed loss estimates, as one might expect if the reforms reduced not only initial reported losses but also the subsequent temporal distribution of losses. For the basic OLS estimates and fixed effects OLS results, the magnitudes of the reform variable effects are generally larger than in Table 3, especially for the estimates using the tenth year development of losses. In these results, the noneconomic damages cap is now statistically significant and of substantial magnitude in the fixed effects OLS regressions. The estimated coefficient suggests that a 10 percent increase in the share of business in states with noneconomic damages caps results in a 3.98 percent decrease in losses. Notably, the fixed effects results for the two sets of developed loss regressions are more similar to the base case OLS results than they were for the reported loss regressions.

For the fifth year and tenth year developed loss estimates, the quantile regression estimates indicate extremely large negative effects of the reform efforts at the median, 
$75^{\text {th }}$ and $90^{\text {th }}$ percentiles. Thus, the developed loss experience indicates a broader effect of the reforms across the distribution of losses than do the reported loss regressions. While on average the tort reforms reduce losses throughout the market, the main effect of the reform efforts is concentrated among the firms that would otherwise have exhibited the worst loss experience. The estimates for the tenth year developed losses indicate that a 10 percent increase in the share of business in states with noneconomic damages caps or punitive damages caps are associated with loss reductions of 4.58 percent and 3.92 percent, respectively, at the $90^{\text {th }}$ percentile. While some reforms are not significant below the median, the significant effects are all negative, as expected. The comparison of the reform effects on the initially reported losses to their effects on the developed losses indicates that insurers generally underestimated the effects of reforms.

\section{Conclusion}

Earlier work suggested that certain malpractice tort reforms have the intended effect on malpractice losses reported by insurance companies. Caps on non-economic damages and limits on joint and several liability are associated with lower levels of reported losses. Because reported losses are heavily weighted toward reserves for claims to be paid in the future, the earlier work largely measured the effect that insurers predicted that tort reform would have on damage awards and settlements, as opposed to the actual effect that tort reform had on awards and settlements. Using developed losses, this research confirms that tort reforms do have the intended effect on the overall level of awards and settlements that insurers pay, and the effect appears to be even larger than insurers predicted. But the effect is not evenly distributed throughout the insurance 
market. In general, insurers with the largest losses obtain the greatest reductions in those losses from tort reform, suggesting that the impact of tort reform is greatest on large claims. 


\section{References}

American Medical Association. 2004. The Physician Professional Liability market and Regulatory Environment. August, 2004.

Baker, Tom. 1998. Transforming Punishment into Compensation: In the Shadow of Punitive Damages. Wisconsin Law Review. 1998: 211-36.

2005. Medical Malpractice and the Insurance Underwriting Cycle. DePaul L. Rev. 54:393.

Barker, Drucilla K. 1992. The Effects of Tort Reform on Medical Malpractice Insurance Markets: An Empirical Analysis, Journal of Health Politics, Policy and Law 17: 143.

Bierens, Herman J. and David E. Bradford. 2005. Are Property-Casualty Insurance Reserves Biased? A Non-Standard Random Effects Panel Data Analysis. Unpublished manuscript, Pennsylvania State University.

Born, Patricia H. 2000. The Insurer Profitability in Different Regulatory and Legal Environments, Journal of Regulatory Economics, 19 (3): 211-237.

Born, Patricia H. and W. Kip Viscusi, 1998. The Distribution of the Insurance Market Effects of Tort Liability Reforms, Brookings Papers on Economic Activity: Microeconomics, 1998.

Danzon, Patricia. 1984. The Frequency and Severity of Medical Malpractice Claims. Journal of Law \& Economics 17:115-48.

------ 1986. The Frequency and Severity of of Medical Malpractice Claims. Law and Contemporary Problems 49:57-84.

Gaver, J. J., and Paterson, J S. 1999. Managing Insurance Company Financial Statements to Meet Regulatory and Tax Reporting Goals. Contemporary Accounting Research, 16 (2): 207-241.

Grace, E.V. 1990. Property-Liability Insurer Reserve Errors: A Theoretical and Empirical Analysis. Journal of Risk \& Insurance, 57 (1), 28-46.

Kazenski, P.M., Feldhaus, W. R., and Schneider, H. C. 1992. Empirical Evidence for Alternative Loss Development Horizons and the Measurement of Reserve Error, Journal of Risk and Insurance, 59 (4).

Koenker, Roger and Gilbert Bassett, Jr., 1978. "Regression Quantiles,” Econometrica 46: 33-50. 
Koenker, Roger and Gilbert Bassett, Jr., 1982. "Robust Tests for Heteroskedasticity Based on Regression Quantiles.” Econometrica 50: 43-61.

Nelson, K. K. 2000. Rate Regulation, Competition, and Loss Reserve Discounting by Property-Casualty Insurers. The Accounting Review, 75 (1), 115-138.

Pace, Nicholas, et al 2004. Capping Non-Economic Awards in Medical Malpractice Trials: California Jury Verdicts Under MICRA. Santa Monica: RAND.

Sloan, Frank, Paula Mergenhagen, Randall R. Bovbjerg. 1989. Effects of Tort Reforms on the Value of Closed Medical Malpractice Claims: A Microanalysis. Journal of Health Politics, Policy and Law 14:663-89.

Studdert, David, Tony Yang, Michelle Mello. 2004. Are Damage Caps Regressive? A Study of Malpractice Verdicts in California, Health Affairs, July-August 2004 at 54.

Viscusi, W. Kip and Patricia Born, 1995. Medical Malpractice Insurance in the Wake of Liability Reform. Journal of Legal Studies. 24: 463-490.

Weiss, M. 1985. A Multivariate Analysis of Loss Reserving Errors in Property-Liability Insurance Companies. Journal of Risk and Insurance (June): 199-221.

Zuckerman, S., Randall R. Bovberg, Frank Sloan. 1990. Effects of Tort Reforms and Other Factors on Medical Malpractice Insurance Premiums. Inquiry 27:167-82.

Yoon, Albert. 2001. Damage Caps and Civil Litigation: An Empirical Study of Medical Malpractice Litigation in the South. Amer. Law \& Econ. Rev. 3:199-227. 
Table 1. Sample means, 1984-2003 $(\mathrm{N}=4552)$

\begin{tabular}{|c|c|c|}
\hline \multicolumn{2}{|l|}{ Variable } & $\begin{array}{c}\text { Mean } \\
\text { (Standard Deviation) }\end{array}$ \\
\hline \multicolumn{2}{|c|}{ Premiums Earned (in millions) } & $\begin{array}{c}14.952 \\
(51.439) \\
\end{array}$ \\
\hline \multicolumn{2}{|c|}{ Losses Incurred - Current Year (in millions) } & $\begin{array}{c}16.645 \\
(60.995)\end{array}$ \\
\hline \multirow[t]{5}{*}{$\begin{array}{l}\text { Share of Business } \\
\text { in States with: }\end{array}$} & Modified Joint \& Several Liability & $\begin{array}{c}0.433 \\
(0.444) \\
\end{array}$ \\
\hline & Modified Collateral Sources Rule & $\begin{array}{c}0.408 \\
(0.428)\end{array}$ \\
\hline & Noneconomic Damages Cap & $\begin{array}{c}0.226 \\
(0.334) \\
\end{array}$ \\
\hline & Punitive Damages Cap & $\begin{array}{c}0.188 \\
(0.313) \\
\end{array}$ \\
\hline & Prior Approval Rate Regulations & $\begin{array}{c}0.336 \\
(0.390) \\
\end{array}$ \\
\hline \multicolumn{2}{|c|}{ Number of States in which Insurer Writes Med Mal } & $\begin{array}{c}9.323 \\
(15.184) \\
\end{array}$ \\
\hline \multirow[t]{4}{*}{$\begin{array}{l}\text { Organizational } \\
\text { Form }\end{array}$} & Stock & $\begin{array}{c}0.823 \\
(0.382)\end{array}$ \\
\hline & Mutual & $\begin{array}{c}0.072 \\
(0.259)\end{array}$ \\
\hline & Reciprocal Exchange & $\begin{array}{c}0.046 \\
(0.209)\end{array}$ \\
\hline & Lloyds & $\begin{array}{c}0.004 \\
(0.064) \\
\end{array}$ \\
\hline
\end{tabular}

Source: National Association of Insurance Commissioners. Note that the number of insurers in the sample ranges from 142 to 342 per year. 
Table 2. Average share of insurer business in states with tort reforms and prior approval rate regulation

\begin{tabular}{|l|c|c|c|}
\hline Share variable & $\begin{array}{c}\text { Mean } \\
1984\end{array}$ & $\begin{array}{c}\text { Mean } \\
1992\end{array}$ & $\begin{array}{c}\text { Mean } \\
2003\end{array}$ \\
\hline Modified Joint \& Several Liability & 0.000 & 0.449 & 0.422 \\
\hline Modified Collateral Source Rule & 0.106 & 0.391 & 0.468 \\
\hline Noneconomic Damages Cap & 0.082 & 0.212 & 0.216 \\
\hline Punitive Damages Cap & 0.000 & 0.145 & 0.288 \\
\hline Prior Approval Rate Regulation & 0.322 & 0.343 & 0.341 \\
\hline
\end{tabular}

* Sources include the American Medical Association (2004), the American Tort Reform Association, and individual state statutes. 
Figure 1. Industry Losses using Reported, 5-year and 10-year Developed Losses, 1980-2003.

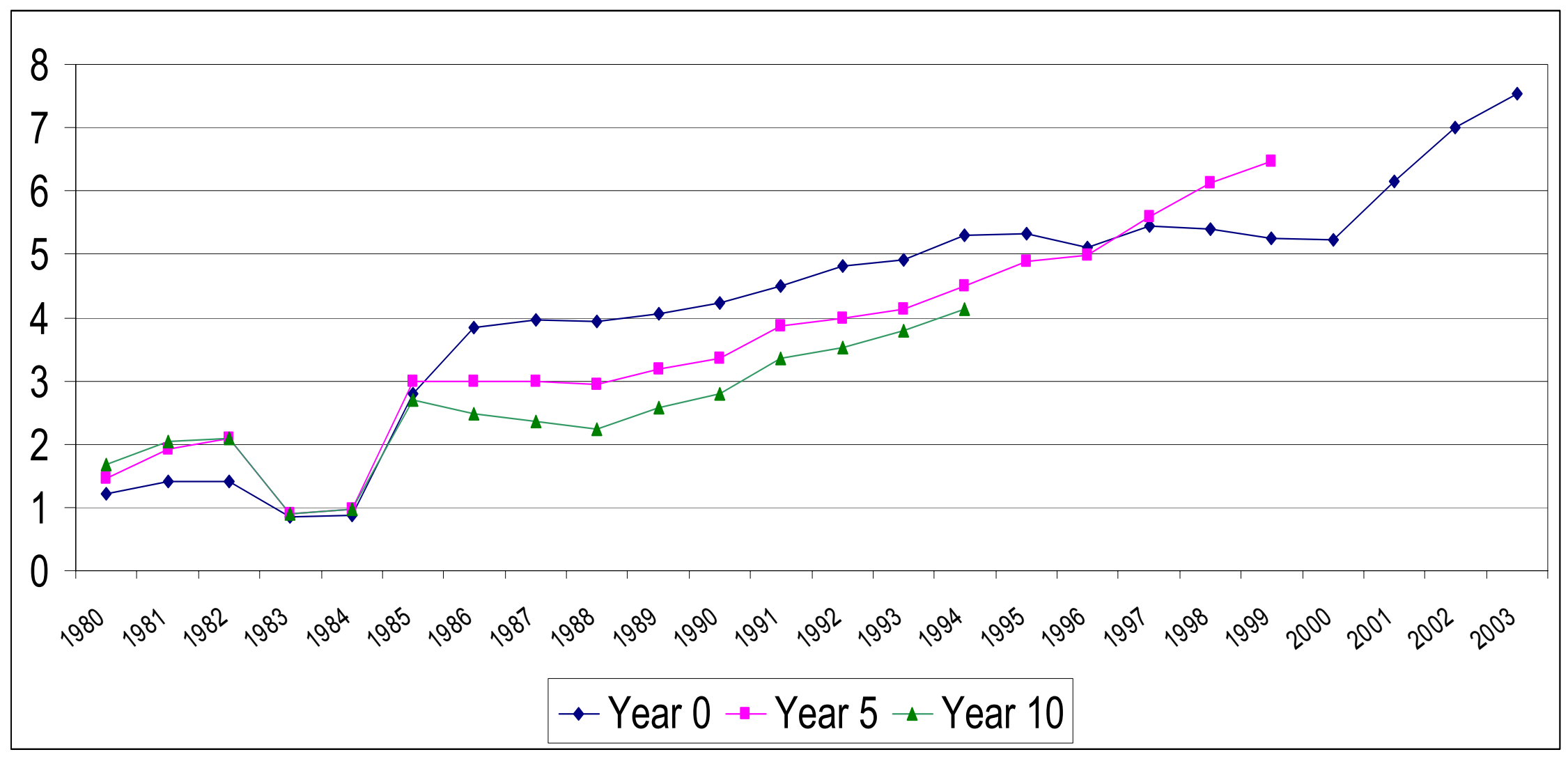


Table 3. OLS and Quantile Regression Results. Dependent Variable $=$ Reported Losses

\begin{tabular}{|c|c|c|c|c|c|c|c|}
\hline & OLS & $\begin{array}{c}\text { OLS } \\
\text { w/fixed } \\
\text { effects }\end{array}$ & $10 \%$ & $25 \%$ & $50 \%$ & $75 \%$ & $90 \%$ \\
\hline Ln(Premiums Earned) & $\begin{array}{l}0.985 * * * \\
(0.007)\end{array}$ & $\begin{array}{l}0.751 * * * \\
(0.014)\end{array}$ & $\begin{array}{l}1.109 * * * \\
(0.011)\end{array}$ & $\begin{array}{l}1.062 * * * \\
(0.005)\end{array}$ & $\begin{array}{l}1.043 * * * \\
(0.003)\end{array}$ & $\begin{array}{l}1.004 * * * \\
(0.005)\end{array}$ & $\begin{array}{l}0.924 * * * \\
(0.011)\end{array}$ \\
\hline $\begin{array}{l}\mathrm{Ln}(\text { Share PW in States w/ } \\
\text { Noneconomic damages cap) }\end{array}$ & $\begin{array}{l}-0.032 \\
(0.066)\end{array}$ & $\begin{array}{c}0.095 \\
(0.095)\end{array}$ & $\begin{array}{c}0.056 \\
(0.067)\end{array}$ & $\begin{array}{c}0.027 \\
(0.033)\end{array}$ & $\begin{array}{l}-0.027 \\
(0.031)\end{array}$ & $\begin{array}{l}-0.087 * * * \\
(0.028)\end{array}$ & $\begin{array}{l}-0.152 * * \\
(0.065)\end{array}$ \\
\hline $\begin{array}{l}\text { Ln(Share PW in States w/ } \\
\text { Punitive damages cap) }\end{array}$ & $\begin{array}{l}-0.178 * * * \\
(0.068)\end{array}$ & $\begin{array}{l}-0.041 \\
(0.091)\end{array}$ & $\begin{array}{l}-0.015 \\
(0.069)\end{array}$ & $\begin{array}{l}-0.083 * * \\
(0.036)\end{array}$ & $\begin{array}{l}-0.113 * * * \\
(0.030)\end{array}$ & $\begin{array}{l}-0.254 * * * \\
(0.041)\end{array}$ & $\begin{array}{l}-0.397 * * * \\
(0.079)\end{array}$ \\
\hline $\begin{array}{l}\text { Ln(Share PW in Joint/Several } \\
\text { Reformed States) }\end{array}$ & $\begin{array}{l}-0.146^{* *} \\
(0.076)\end{array}$ & $\begin{array}{l}-0.335 * * * \\
(0.096)\end{array}$ & $\begin{array}{l}0.178 * \\
(0.102)\end{array}$ & $\begin{array}{c}0.053 \\
(0.053)\end{array}$ & $\begin{array}{l}-0.013 \\
(0.036)\end{array}$ & $\begin{array}{l}-0.133 * * * \\
(0.048)\end{array}$ & $\begin{array}{l}-0.398 * * \\
(0.180)\end{array}$ \\
\hline $\begin{array}{l}\text { Ln(Share PW in Collateral } \\
\text { Source Reformed States) }\end{array}$ & $\begin{array}{l}-0.116 \\
(0.076)\end{array}$ & $\begin{array}{l}-0.025 \\
(0.101)\end{array}$ & $\begin{array}{l}-0.052 \\
(0.083)\end{array}$ & $\begin{array}{l}-0.047 \\
(0.052)\end{array}$ & $\begin{array}{l}-0.078 * \\
(0.048)\end{array}$ & $\begin{array}{l}-0.153 * * * \\
(0.035)\end{array}$ & $\begin{array}{c}0.067 \\
(0.121) \\
\end{array}$ \\
\hline $\begin{array}{l}\text { Ln(Share PW in States with Prior } \\
\text { Approval) }\end{array}$ & $\begin{array}{c}0.069 \\
(0.061)\end{array}$ & $\begin{array}{c}0.036 \\
(0.110)\end{array}$ & $\begin{array}{l}-0.062 \\
(0.071)\end{array}$ & $\begin{array}{l}-0.003 \\
(0.041)\end{array}$ & $\begin{array}{l}-0.009 \\
(0.026)\end{array}$ & $\begin{array}{l}-0.018 \\
(0.035)\end{array}$ & $\begin{array}{c}0.074 \\
(0.077)\end{array}$ \\
\hline Ln(Number of States) & $\begin{array}{c}0.010 \\
(0.012) \\
\end{array}$ & $\begin{array}{l}0.199 * * * \\
(0.022)\end{array}$ & $\begin{array}{l}-0.031 * * \\
(0.013)\end{array}$ & $\begin{array}{l}-0.028 * * * \\
(0.008)\end{array}$ & $\begin{array}{l}-0.027 * * * \\
(0.007)\end{array}$ & $\begin{array}{l}-0.008 \\
(0.010)\end{array}$ & $\begin{array}{c}0.027 \\
(0.019) \\
\end{array}$ \\
\hline Ln(Real Treasury Bill Rate) & $\begin{array}{l}5.746 * * * \\
(1.106)\end{array}$ & $\begin{array}{c}1.009 \\
(1.041)\end{array}$ & $\begin{array}{l}-1.729 \\
(1.542)\end{array}$ & $\begin{array}{l}1.935 * * * \\
(0.608)\end{array}$ & $\begin{array}{l}3.423 * * * \\
(0.581)\end{array}$ & $\begin{array}{l}5.463 * * * \\
(0.747)\end{array}$ & $\begin{array}{l}9.052 * * * \\
(1.042)\end{array}$ \\
\hline Mutual & $\begin{array}{l}0.197 * * * \\
(0.053)\end{array}$ & & $\begin{array}{c}0.003 \\
(0.065)\end{array}$ & $\begin{array}{l}0.085^{* *} \\
(0.037)\end{array}$ & $\begin{array}{l}0.078 * * * \\
(0.025)\end{array}$ & $\begin{array}{c}0.032 \\
(0.037)\end{array}$ & $\begin{array}{c}0.172 \\
(0.111)\end{array}$ \\
\hline Lloyds & $\begin{array}{l}-0.364 \\
(0.260) \\
\end{array}$ & & $\begin{array}{c}0.494 \\
(2.377) \\
\end{array}$ & $\begin{array}{c}0.382 * \\
(0.207)\end{array}$ & $\begin{array}{l}0.254^{* * *} \\
(0.129)\end{array}$ & $\begin{array}{l}-0.013 \\
(0.084)\end{array}$ & $\begin{array}{l}-0.334 * * \\
(0.168)\end{array}$ \\
\hline Reciprocal & $\begin{array}{l}0.133 * * \\
(0.064)\end{array}$ & & $\begin{array}{c}0.053 \\
(0.068)\end{array}$ & $\begin{array}{l}0.129 * * * \\
(0.035)\end{array}$ & $\begin{array}{l}0.071 * * * \\
(0.022)\end{array}$ & $\begin{array}{c}0.041 * \\
(0.024)\end{array}$ & $\begin{array}{c}0.031 \\
(0.051)\end{array}$ \\
\hline Intercept & $\begin{array}{l}-0.020 \\
(0.070)\end{array}$ & $\begin{array}{l}1.595 * * * \\
(0.119)\end{array}$ & $\begin{array}{l}-1.554 * * * \\
(0.103)\end{array}$ & $\begin{array}{l}-0.888 * * * \\
(0.038)\end{array}$ & $\begin{array}{l}-0.462 * * * \\
(0.041)\end{array}$ & $\begin{array}{l}0.244 * * * \\
(0.068)\end{array}$ & $\begin{array}{l}1.219 * * * \\
(0.152) \\
\end{array}$ \\
\hline Adjusted $\mathrm{R}^{2 \dagger}$ & 0.888 & 0.871 & 0.741 & 0.786 & 0.782 & 0.730 & 0.640 \\
\hline
\end{tabular}

${ }^{\dagger}$ Overall $\mathrm{R}^{2}$ for fixed effects model and pseudo $\mathrm{R}^{2}$ for quantile regressions

$* * *, * *$ and $*$ indicate estimated coefficients that are significant at the $99 \%, 95 \%$, and $90 \%$ significance levels, respectively. 
Table 4. OLS and Quantile Regression Results. Dependent Variable = Developed Losses, fifth year

\begin{tabular}{|c|c|c|c|c|c|c|c|}
\hline & OLS & $\begin{array}{c}\text { OLS } \\
\text { w/fixed } \\
\text { effects }\end{array}$ & $10 \%$ & $25 \%$ & $50 \%$ & $75 \%$ & $90 \%$ \\
\hline Ln(Premiums Earned) & $\begin{array}{l}0.979 * * * \\
(0.010)\end{array}$ & $\begin{array}{l}0.720 * * * \\
(0.023)\end{array}$ & $\begin{array}{l}1.229 * * * \\
(0.021)\end{array}$ & $\begin{array}{l}1.106 * * * \\
(0.015)\end{array}$ & $\begin{array}{l}1.021 * * * \\
(0.009)\end{array}$ & $\begin{array}{l}0.945 * * * \\
(0.013)\end{array}$ & $\begin{array}{l}0.854 * * * \\
(0.015)\end{array}$ \\
\hline $\begin{array}{l}\text { Ln(Share PW in States w/ } \\
\text { Noneconomic damages cap) }\end{array}$ & $\begin{array}{l}-0.085 \\
(0.099)\end{array}$ & $\begin{array}{c}0.096 \\
(0.140)\end{array}$ & $\begin{array}{l}0.238^{* *} \\
(0.105)\end{array}$ & $\begin{array}{l}-0.030 \\
(0.073)\end{array}$ & $\begin{array}{l}-0.121 * * \\
(0.053)\end{array}$ & $\begin{array}{l}-0.215 * * * \\
(0.059)\end{array}$ & $\begin{array}{l}-0.251 * * * \\
(0.081)\end{array}$ \\
\hline $\begin{array}{l}\text { Ln(Share PW in States w/ } \\
\text { Punitive damages cap) }\end{array}$ & $\begin{array}{l}-0.129 \\
(0.108)\end{array}$ & $\begin{array}{c}0.000 \\
(0.139) \\
\end{array}$ & $\begin{array}{c}0.012 \\
(0.154)\end{array}$ & $\begin{array}{l}-0.043 \\
(0.067)\end{array}$ & $\begin{array}{l}-0.162 * * * \\
(0.058)\end{array}$ & $\begin{array}{l}-0.094 \\
(0.075)\end{array}$ & $\begin{array}{l}-0.189 * \\
(0.113)\end{array}$ \\
\hline $\begin{array}{l}\text { Ln(Share PW in Joint/Several } \\
\text { Reformed States) }\end{array}$ & $\begin{array}{l}-0.220 * \\
(0.123)\end{array}$ & $\begin{array}{l}-0.401 * * * \\
(0.148)\end{array}$ & $\begin{array}{c}0.149 \\
(0.174)\end{array}$ & $\begin{array}{l}-0.019 \\
(0.081)\end{array}$ & $\begin{array}{l}-0.094 \\
(0.085)\end{array}$ & $\begin{array}{l}-0.249 * * * \\
(0.095)\end{array}$ & $\begin{array}{l}-0.651 * * * \\
(0.195)\end{array}$ \\
\hline $\begin{array}{l}\text { Ln(Share PW in Collateral } \\
\text { Source Reformed States) }\end{array}$ & $\begin{array}{l}-0.184 \\
(0.122) \\
\end{array}$ & $\begin{array}{c}0.063 \\
(0.158) \\
\end{array}$ & $\begin{array}{l}-0.431 * * \\
(0.180)\end{array}$ & $\begin{array}{l}-0.223 * * * \\
(0.087)\end{array}$ & $\begin{array}{l}-0.232 * * * \\
(0.085)\end{array}$ & $\begin{array}{l}-0.101 \\
(0.088)\end{array}$ & $\begin{array}{c}0.090 \\
(0.125) \\
\end{array}$ \\
\hline $\begin{array}{l}\text { Ln(Share PW in States with Prior } \\
\text { Approval) }\end{array}$ & $\begin{array}{c}0.106 \\
(0.092) \\
\end{array}$ & $\begin{array}{c}0.101 \\
(0.165) \\
\end{array}$ & $\begin{array}{c}0.078 \\
(0.162) \\
\end{array}$ & $\begin{array}{c}0.130 \\
(0.082) \\
\end{array}$ & $\begin{array}{c}0.085 \\
(0.084) \\
\end{array}$ & $\begin{array}{c}0.055 \\
(0.080) \\
\end{array}$ & $\begin{array}{c}0.181 \\
(0.114) \\
\end{array}$ \\
\hline Ln(Number of States) & $\begin{array}{l}0.054 * * * \\
(0.018)\end{array}$ & $\begin{array}{l}0.254 * * * \\
(0.034)\end{array}$ & $\begin{array}{l}-0.022 \\
(0.034)\end{array}$ & $\begin{array}{c}0.010 \\
(0.012) \\
\end{array}$ & $\begin{array}{c}0.022 \\
(0.014) \\
\end{array}$ & $\begin{array}{l}0.068 * * * \\
(0.014)\end{array}$ & $\begin{array}{l}0.094 * * * \\
(0.017) \\
\end{array}$ \\
\hline Ln(Real Treasury Bill Rate) & $\begin{array}{l}12.503 * * * \\
(2.036)\end{array}$ & $\begin{array}{l}8.148 * * * \\
(1.835)\end{array}$ & $\begin{array}{c}-10.971 * * * \\
(2.744)\end{array}$ & $\begin{array}{c}0.726 \\
(1.578) \\
\end{array}$ & $\begin{array}{l}8.066 * * * \\
(2.696)\end{array}$ & $\begin{array}{l}13.801 * * * \\
(1.700)\end{array}$ & $\begin{array}{l}22.181 * * * \\
(2.866)\end{array}$ \\
\hline Mutual & $\begin{array}{l}0.247 * * * \\
(0.079)\end{array}$ & & $\begin{array}{c}0.138 \\
(0.121) \\
\end{array}$ & $\begin{array}{l}0.182 * * * \\
(0.036)\end{array}$ & $\begin{array}{l}0.113 * * * \\
(0.044)\end{array}$ & $\begin{array}{l}0.202 * * * \\
(0.060)\end{array}$ & $\begin{array}{l}0.263 * * * \\
(0.071)\end{array}$ \\
\hline Lloyds & $\begin{array}{l}-0.323 \\
(0.339)\end{array}$ & & $\begin{array}{c}0.877 \\
(1.025)\end{array}$ & $\begin{array}{c}0.188 \\
(0.411) \\
\end{array}$ & $\begin{array}{l}-0.066 \\
(0.329)\end{array}$ & $\begin{array}{l}-0.535 \\
(0.260)\end{array}$ & $\begin{array}{l}-0.579 \\
(0.388) \\
\end{array}$ \\
\hline Reciprocal & $\begin{array}{c}0.183 * \\
(0.097)\end{array}$ & & $\begin{array}{c}0.113 \\
(0.074)\end{array}$ & $\begin{array}{l}0.135 * * \\
(0.054)\end{array}$ & $\begin{array}{l}0.117 * * * \\
(0.037)\end{array}$ & $\begin{array}{l}0.118 * * \\
(0.047)\end{array}$ & $\begin{array}{l}0.107 * * \\
(0.055)\end{array}$ \\
\hline Intercept & $\begin{array}{l}-0.293 * * \\
(0.117) \\
\end{array}$ & $\begin{array}{l}1.442 * * * \\
(0.197)\end{array}$ & $\begin{array}{l}-2.832 * * * \\
(0.211) \\
\end{array}$ & $\begin{array}{l}-1.471 * * * \\
(0.164)\end{array}$ & $\begin{array}{l}-0.415 * * * \\
(0.106)\end{array}$ & $\begin{array}{l}0.481 * * * \\
(0.110)\end{array}$ & $\begin{array}{l}1.641 * * * \\
(0.186) \\
\end{array}$ \\
\hline Adjusted $\mathrm{R}^{2 \dagger}$ & 0.806 & 0.782 & 0.613 & 0.660 & 0.669 & 0.629 & 0.559 \\
\hline
\end{tabular}

${ }^{\dagger}$ Overall $\mathrm{R}^{2}$ for fixed effects model and pseudo $\mathrm{R}^{2}$ for quantile regressions

$* * *, * *$ and $*$ indicate estimated coefficients that are significant at the $99 \%, 95 \%$, and $90 \%$ significance levels, respectively. 
Table 5. OLS and Quantile Regression Results. Dependent Variable = Developed Losses, tenth year

\begin{tabular}{|c|c|c|c|c|c|c|c|}
\hline & OLS & $\begin{array}{c}\text { OLS } \\
\text { w/fixed } \\
\text { effects }\end{array}$ & $10 \%$ & $25 \%$ & $50 \%$ & $75 \%$ & $90 \%$ \\
\hline Ln(Premiums Earned) & $\begin{array}{l}0.917 * * * \\
(0.014)\end{array}$ & $\begin{array}{l}0.626 * * * \\
(0.032)\end{array}$ & $\begin{array}{l}1.181 * * * \\
(0.026)\end{array}$ & $\begin{array}{l}1.073 * * * \\
(0.009)\end{array}$ & $\begin{array}{l}0.971 * * * \\
(0.009)\end{array}$ & $\begin{array}{l}0.879 * * * \\
(0.013)\end{array}$ & $\begin{array}{l}0.798 * * * \\
(0.034)\end{array}$ \\
\hline $\begin{array}{l}\text { Ln(Share PW in States w/ } \\
\text { Noneconomic damages cap) }\end{array}$ & $\begin{array}{l}-0.222 \\
(0.141)\end{array}$ & $\begin{array}{l}-0.398 * \\
(0.207)\end{array}$ & $\begin{array}{c}0.034 \\
(0.196)\end{array}$ & $\begin{array}{l}-0.151 * \\
(0.090)\end{array}$ & $\begin{array}{l}-0.184 * * * \\
(0.066)\end{array}$ & $\begin{array}{l}-0.292 * * * \\
(0.070)\end{array}$ & $\begin{array}{l}-0.458 * * \\
(0.189)\end{array}$ \\
\hline $\begin{array}{l}\text { Ln(Share PW in States w/ } \\
\text { Punitive damages cap) }\end{array}$ & $\begin{array}{l}-0.291 * \\
(0.155)\end{array}$ & $\begin{array}{l}-0.168 \\
(0.215)\end{array}$ & $\begin{array}{c}0.144 \\
(0.256)\end{array}$ & $\begin{array}{l}-0.250 * * \\
(0.099)\end{array}$ & $\begin{array}{l}-0.264 * * * \\
(0.070)\end{array}$ & $\begin{array}{l}-0.291 * * * \\
(0.063)\end{array}$ & $\begin{array}{l}-0.392 * * \\
(0.158)\end{array}$ \\
\hline $\begin{array}{l}\text { Ln(Share PW in Joint/Several } \\
\text { Reformed States) }\end{array}$ & $\begin{array}{l}-0.224 \\
(0.167)\end{array}$ & $\begin{array}{l}-0.373 * \\
(0.208)\end{array}$ & $\begin{array}{c}0.017 \\
(0.283)\end{array}$ & $\begin{array}{l}-0.074 \\
(0.119)\end{array}$ & $\begin{array}{l}-0.218 * * \\
(0.110)\end{array}$ & $\begin{array}{l}-0.250 * * * \\
(0.088)\end{array}$ & $\begin{array}{l}-0.890 * * * \\
(0.272)\end{array}$ \\
\hline $\begin{array}{l}\text { Ln(Share PW in Collateral } \\
\text { Source Reformed States) }\end{array}$ & $\begin{array}{l}-0.286^{*} \\
(0.163) \\
\end{array}$ & $\begin{array}{l}-0.101 \\
(0.219)\end{array}$ & $\begin{array}{l}-0.501 * * \\
(0.217)\end{array}$ & $\begin{array}{l}-0.473 * * * \\
(0.119)\end{array}$ & $\begin{array}{l}-0.331 * * * \\
(0.093)\end{array}$ & $\begin{array}{l}-0.222 * * * \\
(0.095)\end{array}$ & $\begin{array}{r}0.090 \\
(0.193) \\
\end{array}$ \\
\hline $\begin{array}{l}\text { Ln(Share PW in States with Prior } \\
\text { Approval) }\end{array}$ & $\begin{array}{c}0.169 \\
(0.124)\end{array}$ & $\begin{array}{c}0.113 \\
(0.229)\end{array}$ & $\begin{array}{c}0.299 \\
(0.210)\end{array}$ & $\begin{array}{c}0.115 \\
(0.074)\end{array}$ & $\begin{array}{c}0.049 \\
(0.081)\end{array}$ & $\begin{array}{c}0.010 \\
(0.090)\end{array}$ & $\begin{array}{c}0.081 \\
(0.205)\end{array}$ \\
\hline Ln(Number of States) & $\begin{array}{l}0.069 * * * \\
(0.024)\end{array}$ & $\begin{array}{l}0.402 * * * \\
(0.049)\end{array}$ & $\begin{array}{l}-0.013 \\
(0.026)\end{array}$ & $\begin{array}{c}0.020 \\
(0.018) \\
\end{array}$ & $\begin{array}{l}0.053 * * * \\
(0.015)\end{array}$ & $\begin{array}{l}0.067 * * * \\
(0.020)\end{array}$ & $\begin{array}{l}0.110 * * * \\
(0.038)\end{array}$ \\
\hline Ln(Real Treasury Bill Rate) & $\begin{array}{l}13.297 * * * \\
(2.502)\end{array}$ & $\begin{array}{l}6.604 * * * \\
(2.430)\end{array}$ & $\begin{array}{c}-11.471 * * \\
(5.245)\end{array}$ & $\begin{array}{l}-0.425 \\
(1.911)\end{array}$ & $\begin{array}{l}5.010 * * * \\
(1.991)\end{array}$ & $\begin{array}{l}10.110 * * * \\
(2.659)\end{array}$ & $\begin{array}{l}20.466 * * * \\
(4.826)\end{array}$ \\
\hline Mutual & $\begin{array}{l}0.211 * * \\
(0.108)\end{array}$ & & $\begin{array}{c}0.202 * \\
(0.106)\end{array}$ & $\begin{array}{c}0.109 * \\
(0.059)\end{array}$ & $\begin{array}{l}0.121 * * * \\
(0.047)\end{array}$ & $\begin{array}{c}0.141 * \\
(0.077)\end{array}$ & $\begin{array}{c}0.266^{*} \\
(0.141)\end{array}$ \\
\hline Lloyds & $\begin{array}{l}-0.505 \\
(0.374) \\
\end{array}$ & & $\begin{array}{c}0.683 * \\
(0.612)\end{array}$ & $\begin{array}{c}0.191 \\
(0.454) \\
\end{array}$ & $\begin{array}{l}-0.109 \\
(0.189)\end{array}$ & $\begin{array}{l}-0.773 * * * \\
(0.199)\end{array}$ & $\begin{array}{l}-0.686 \\
(0.515) \\
\end{array}$ \\
\hline Reciprocal & $\begin{array}{c}0.325 * * \\
(0.133)\end{array}$ & & $\begin{array}{l}0.424 * * * \\
(0.131)\end{array}$ & $\begin{array}{l}0.274 * * * \\
(0.036)\end{array}$ & $\begin{array}{l}0.313 * * * \\
(0.062)\end{array}$ & $\begin{array}{l}0.272 * * * \\
(0.068)\end{array}$ & $\begin{array}{c}0.235 * * \\
(0.104)\end{array}$ \\
\hline Intercept & $\begin{array}{c}0.085 \\
(0.153) \\
\end{array}$ & $\begin{array}{l}2.010 * * * \\
(0.281)\end{array}$ & $\begin{array}{l}-2.706^{* * * *} \\
(0.300)\end{array}$ & $\begin{array}{l}-1.214^{* * *} \\
(0.105)\end{array}$ & $\begin{array}{l}-0.017 \\
(0.122) \\
\end{array}$ & $\begin{array}{l}1.109 * * * \\
(0.109)\end{array}$ & $\begin{array}{l}2.286 * * * \\
(0.297)\end{array}$ \\
\hline Adjusted $\mathrm{R}^{2 \dagger}$ & 0.761 & 0.696 & 0.577 & 0.618 & 0.622 & 0.577 & 0.486 \\
\hline
\end{tabular}

${ }^{\dagger}$ Overall $\mathrm{R}^{2}$ for fixed effects model and pseudo $\mathrm{R}^{2}$ for quantile regressions

$* * *, * *$ and $*$ indicate estimated coefficients that are significant at the $99 \%, 95 \%$, and $90 \%$ significance levels, respectively. 